\title{
Dual Inhibitors Targeting DNA and Histone Deacetylases
}

\author{
Chen Chen ${ }^{1}$ Xinying Yang ${ }^{2}$ Xuben Hou ${ }^{2}$ Hao Fang ${ }^{2}$ \\ ${ }^{1}$ Department of Pharmaceutical Synthesis and Analysis, Shandong \\ Analysis and Test Center, Qilu University of Technology (Shandong \\ Academy of Sciences), Jinan, People's Republic of China \\ 2 Department of Medicinal Chemistry, Key Laboratory of Chemical \\ Biology, Ministry of Education, School of Pharmaceutical Sciences, \\ Shandong University, Jinan, People's Republic of China \\ Pharmaceut Fronts 2020;2:e88-e93.
}

Address for correspondence Hao Fang, PhD, Department of Medicinal Chemistry, School of Pharmaceutical Sciences, Shandong University, 44 West Culture Road, Jinan, 250012, People’s Republic of China (e-mail: haofangcn@sdu.edu.cn).
Abstract
Keywords
- DNA
- HDAC
- dual-targeting
- antitumor agent

Histone deacetylases (HDACs) regulate the acetylation status of histones and structural status of chromatin. The chromatin structure becomes relaxed after inhibition of HDAC, leading to DNA exposed to DNA disrupting agents, and eventually causing DNA dysfunction. Recently, more and more dual inhibitors targeting DNA and HDACs have been reported to be applied to cancer treatment. In this review, we describe the current status of dual inhibitors targeting DNA and HDACs, summarize their pharmacological characters, and predict their further trend in the field.

\section{Introduction}

Over the last decade, chemotherapeutics and targeted drugs have been the most common and effective approaches for cancer treatment. Due to activation of compensatory mechanisms and multiple signaling pathways, cancer cells become resistant to single-target drugs. ${ }^{1}$ Thus, drug combination treatment gradually attracts the interest of researchers by its advantages such as synergistic effects and less resistance. ${ }^{2}$ Furthermore, lower doses of the individual drugs are used, which means fewer side effects than single-drug treatments. ${ }^{3}$ Currently, drug combination therapies have moved toward the dual- or multi-targeting drugs, ${ }^{4}$ which has raised scientific interest through some advantages such as the more predictable pharmacokinetics and the less risks of drug interactions. ${ }^{5}$ DNA is the most important storage unit of genetic information and plays key roles in replication, transcription, and translation. ${ }^{6}$ Histone deacetylases (HDACs) get rid of acetyl groups from histones and regulate the structure of chromatin. It is reported that the structure of chromatin becomes relaxed after inhibition of HDAC, leading to DNA damage. ${ }^{7}$ Several dual DNA/HDAC inhibitors have been reported, which possess obvious anticancer activity. ${ }^{8}$ This article describes the dual DNA/HDAC inhibitors and their biology activity studies.

\section{DNA and DNA Binders}

Covalent and noncovalent interactions are main processes happening between small molecules and DNA. The interac- tion between alkylating agents and DNA is a covalent interaction (-Fig. 1). The formation of covalent bonds between alkylating agents and DNA leads to the inhibition of replication or transcription. Earlier, doctors used nitrogen mustards, the first-generation alkylating agents, for therapy of leukemias and lymphomas. The nitrogen mustard molecules attack the N7 of guanine to form an aziridinium ion, thereby causing DNA interstrand cross-linking. Other well-known alkylators include platinum derivatives, ${ }^{9}$ oxazaphosphorines, ${ }^{10}$ nitrosoureas, ${ }^{11}$ triazenes, ${ }^{12}$ hydrazines, ${ }^{13}$ and so on.

Intercalation and groove binding belong to noncovalent interactions. DNA intercalators could intercalate and stack between the adjacent DNA base pairs, ${ }^{14}$ which resulted in elongation of the DNA, ${ }^{15}$ finally interrupting the replication, transcription, and DNA repair processes. ${ }^{16}$ Topoisomerases (Topo) could combine with DNA to form a reversible covalent Topo-DNA complex and modulate DNA supercoiling. ${ }^{17}$ Topo inhibitors could intercalate into DNA base pairs and maintain the structure of the DNA-enzyme cleavable complex. ${ }^{18}$ Thus, most of Topo inhibitors are also DNA intercalators (-Fig. 2).

DNA groove binders could bind to the edges of DNA base pairs via reversible noncovalent interactions, ${ }^{19}$ yet the conformation of DNA duplex was changeless. ${ }^{20}$ To adapt with the shape of the minor groove, minor groove binders (MGBs) are often designed as isohelical and crescent-shaped molecules. The common MGBs are listed in - Fig. 3. ISSN 2628-5088.
@ 2020 Georg Thieme Verlag KG
Stuttgart · New York

License terms

(c) $(9$ 
<smiles>Cn1c(CCCC(=O)O)nc2cc(N(CCCl)CCCl)c(C(=O)OC(C)(C)C)cc21</smiles><smiles>N[C@@H](Cc1ccc(N(CCCl)CCCl)cc1)C(=O)O</smiles>

Fig. 1 DNA alkylating agents.

\section{HDACs and HDAC Inhibitors}

As a crucial enzyme in epigenetics regulation, HDACs eliminate the acetyl groups of lysine residues, resulting in a condensed chromatin structure and transcriptional suppression. Eighteen members of human HDACs have been found, and they are subdivided into four classes (-Table $\mathbf{1}$ ).

As the structures of various HDACs were elucidated, lots of HDAC inhibitors have been developed. The common pharmacophore model of HDAC inhibitors comprises a cap group, a linker and a zinc-binding group (ZBG). The linker is usually a saturated or unsaturated fatty chain, or an aromatic and heterocyclic ring, which connects the cap group to ZBG and interacts with a hydrophobic channel of active pocket. ZBG, including hydroxamic acid, carboxylic acid, boric acid, and so

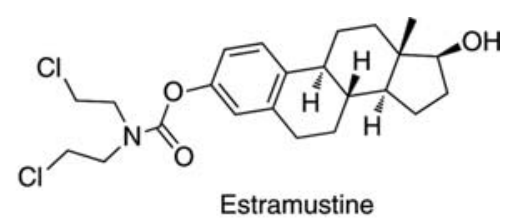<smiles>O=C(O)CCCc1ccc(N(CCCl)CCCl)cc1</smiles>

on, reversibly or irreversibly chelates to $\mathrm{Zn}^{2+}$ at the bottom of the active pocket.

HDAC inhibitors based on hydroxamic acid are the most representative HDAC inhibitors and three drugs have been approved by Food and Drug Administration. Vorinostat, belinostat, and panobinostat were respectively approved for the treatment of relapsed/refractory cutaneous $T$ cell lymphoma, peripheral T cell lymphoma (PTCL), and multiple myeloma. They are all pan-HDAC inhibitors (-Fig. 4).

Valproic acid (VPA) and benzenebutyric acid are weak inhibitors of class I and class II HDACs (-Fig. 5). Among them, VPA is used for the treatment for epilepsy, bipolar disorder, and migraine.

Entinostat (MS-275) and tacedinaline (CI-994) are class I selective HDAC inhibitors. Entinostat is in the third phase of<smiles>COc1cccc2c1C(=O)c1c(O)c3c(c(O)c1C2=O)C[C@@](O)(C(C)=O)C[C@@H]3O[C@@H]1C[C@H](N)[C@H](O)[C@H](C)O1</smiles>

daunomycin<smiles>COc1cccc2c1C(=O)c1c(O)c3c(c(O)c1C2=O)C[C@@](O)(C(=O)CO)C[C@@H]3O[C@@H]1C[C@H](N)[C@H](O)[C@H](C)O1</smiles>

doxorubicin<smiles>O=C1c2c(O)ccc(O)c2C(=O)c2c(NCCNCCO)ccc(NCCNCCO)c21</smiles>

mitoxantrone<smiles>COc1cc(NS(C)(=O)=O)ccc1Nc1c2ccccc2nc2ccccc12</smiles>

m-AMSA<smiles>CN(C)CCNC(=O)c1cccc2cc3ccccc3nc12</smiles>

DACA<smiles>Cc1cccc2nc3cccc(C(=O)NCCNCCNCCNC(=O)c4cccc5nc6cccc(C)c6nc45)c3nc12</smiles>

Fig. 2 DNA intercalators. 
<smiles>Cn1cc(NC(=O)c2cc(NC(=O)c3cc(NC(=O)c4cc(NC(=N)Cl)cn4C)cn3C)cn2C)cn1</smiles>

distamycin<smiles>CN1CCN(c2ccc3[nH]c(-c4ccc5nc(-c6ccc(O)cc6)[nH]c5c4)nc3c2)CC1</smiles>

Hoechst 33258<smiles>Cn1cc(NC(=O)c2cc(NC(=O)CNC(=N)N)cn2C)cc1C(=O)NCCC(=N)N</smiles>

netropsin<smiles>CCOc1ccc(-c2nc3ccc(-c4nc5cc(N6CCN(C)CC6)ccc5[nH]4)cc3[nH]2)cc1</smiles>

Hoechst 33342<smiles>N=C(N)c1ccc(N=NNc2ccc(C(=N)N)cc2)cc1</smiles>

diminazene<smiles>N=C(N)c1ccc(-c2cc3ccc(C(=N)N)cc3[nH]2)cc1</smiles>

DAPI<smiles>N=C(N)c1ccc(OCCCCCOc2ccc(C(=N)N)cc2)cc1</smiles>

pentamidine

Fig. 3 DNA minor groove binders.

Table 1 The human HDAC family: classes and names

\begin{tabular}{|l|l|}
\hline Classes & Names \\
\hline Class I & HDAC 1, 2, 3, 8 \\
\hline Class II & $\begin{array}{l}\text { Ila: HDAC 4, 5, 7, 9 } \\
\text { Ilb: HDAC 6, 10 }\end{array}$ \\
\hline Class III (sirtuins) & Sirtuin1-7 \\
\hline Class IV & HDAC11 \\
\hline
\end{tabular}

Abbreviation: HDAC, histone deacetylase.

clinical treatment for breast cancer. Chidamide is a Chinese original class I selective HDAC inhibitor against relapsed/ refractory PTCL. Their structures are listed in - Fig. 6 .

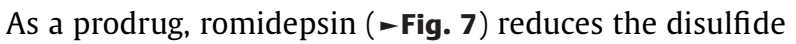
bond to a thiol, reaching the active center of class I HDACs, in turn sequestering $\mathrm{Zn}^{2+}$ to exert HDAC inhibitory activity.

\section{Dual Inhibitors Targeting DNA and HDACs}

\section{Dual Inhibitors Based on Nitrogen Mustards}

In 2015, Liu et al developed and characterized a novel dualtargeting HDAC/DNA drug based on bendamustine. ${ }^{21}$ The representative drug CY190602 showed significantly improved anticancer activity in vitro and in vivo (Scheme 1). Meanwhile, CY190602 was used as a tool to explore the role of HDAC in<smiles>CCCC(CCC)C(=O)O</smiles>

Valproic acid, VPA<smiles>O=C(O)CCCc1ccccc1</smiles>

Benzenebutyric acid
Fig. 5 Structures of VPA and benzenebutyric acid.

DNA damage and repair. As a result, it was found that the expression of TYMS, Tip60, CBP, EP300, and MSL1, which participate in DNA synthesis and repair, was related to HDAC activity. These findings provide rationales for dualtargeting inhibitors, to overcome the resistance of cancer cells.

Based on the strategy of combination of nitrogen and hydroxamic acid, Xie et al reported a series of chlorambucil derivatives with a hydroxamic acid tail and assayed the inhibitory activities of these derivatives on DNA and total HDACs. ${ }^{22}$ The results showed that vorambucil (Scheme 2) possessed good HDAC1, HDAC2, and HDAC6 inhibitory activities with micromolar level $\mathrm{IC}_{50}$ values. In addition, vorambucil showed potent antiproliferative activity against A375 cancer cells and could significantly inhibit their colony formation. Meanwhile, vorambucil remarkably affected cancer cell apoptosis and cycle.

In 2018, a dual-targeting inhibitor named chlordinaline was reported (Scheme 3). ${ }^{23}$ Chlordinaline exhibited moderate total HDAC inhibitory activity and selectivity and HDAC3<smiles>O=C(CCCCCCC(=O)Nc1ccccc1)NO</smiles>

Vorinostat, SAHA<smiles>O=C(/C=C/c1cccc(S(=O)(=O)Nc2ccccc2)c1)NO</smiles>

Belinostat, PXD-101<smiles>Cc1[nH]c2ccccc2c1CCNCc1ccc(/C=C/C(=O)NO)cc1</smiles>

Panobinostat, LBH-589

Fig. 4 Structures of vorinostat, belinostat, and panobinostat. 
<smiles>Nc1ccccc1NC(=O)c1ccc(CNC(=O)OCc2cccnc2)cc1</smiles>

Entinostat, MS-275<smiles>Nc1ccc(F)cc1NC(=O)c1ccc(CNC(=O)/C=C/c2cccnc2)cc1</smiles><smiles>CC(=O)Nc1ccc(C(=O)Nc2ccccc2N)cc1</smiles>

Tacedinaline, Cl-994<smiles>COC(C)(C)COC(C)(C)C</smiles>

Fig. 6 The structures of entinostat, etc.

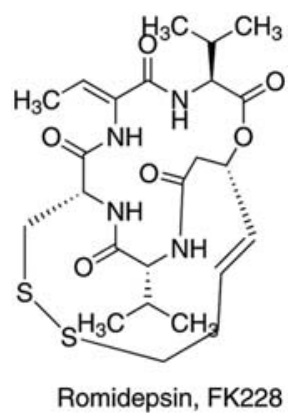

Fig. 7 Structures of romidepsin.

inhibitory activity. For A549, A375, SMMC7721, HepG2, H1299, and H460 cell lines, chlordinaline showed more potent antiproliferative activity than the reference drugs chlorambucil and tacedinaline. In addition, chlordinaline could induce the apoptosis and G2/M phase cell-cycle arrest of A375 cancer cells. Xie et al's research demonstrates that a single molecule containing nitrogen mustard and 2-amino-<smiles>Cn1c(CCCC(=O)O)nc2cc(N(CCCl)CCCl)ccc21</smiles>

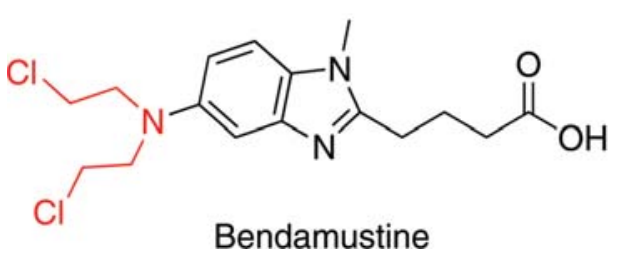<smiles>Cn1c(CCCC(=O)O)nc2cc(N(CCCl)CCCl)ccc21</smiles>

benzamide or hydroxamic acid fragment may be a potent antitumor agent owing to its DNA-binding activity and HDAC inhibitory activity.

\section{Dual Inhibitors Based on Metal Complexes}

In 2009, Griffith et al reported the first Pt complex with dual DNA-binding and HDAC inhibitory activity. ${ }^{24}$ Agarose gel electrophoretic assay verified that the Pt complex 3 (- Fig. 8) bound to nucleotides leading to the DNA strands unwrapping. Pt complex 3 showed moderate inhibitory activity against HDAC1 with $\mathrm{IC}_{50}$ values as low as $1 \mu \mathrm{mol} / \mathrm{L}$. Furthermore, for A2780P cell lines, Pt complex 3 had a similar cytotoxicity ( IC $_{50}$ $9 \mu \mathrm{mol} / \mathrm{L}$ ) as compared with cisplatin $\left(\mathrm{IC}_{50} 3 \mu \mathrm{mol} / \mathrm{L}\right.$ ), but for<smiles>CC(C)(C)OC(=O)CCCCCCC(=O)Nc1ccc(CC2C(=O)OP(N)(N)(N)OC2=O)cc1</smiles>

Fig. 8 Structure of Pt complex 3.<smiles>Cn1c(CCCCCCC(=O)NO)nc2cc(N(CCCl)CCCl)ccc21</smiles>

CY190602<smiles>Cn1c(CCCCCCC(=O)NO)nc2cc(N(CCCl)CCCl)ccc21</smiles>

CY190602<smiles>Cn1c(CCCCCCC(=O)NO)nc2cc(N(CCCl)CCCl)ccc21</smiles> 


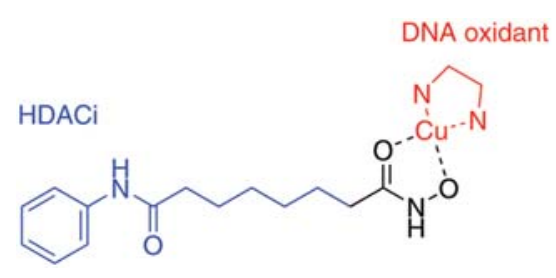

Fig. 9 Structure of $\mathrm{Cu}$ (II) prodrugs.

normal human dermal fibroblast cells, Pt complex 3 is less toxic than cisplatin ( $\mathrm{IC}_{50} 83 \mathrm{vs}$. $\left.\mathrm{IC}_{50} 10 \mu \mathrm{mol} / \mathrm{L}\right)$.

McGivern et al designed and developed a series of $\mathrm{Cu}$ (II) prodrugs containing SAHA and phenanthrene ligands as DNA intercalators (-Fig. 9). ${ }^{25}$ It was proved that the complex preferred to intercalate at both A-T- and G-C-rich sequences, resulting in DNA damage by yielding reactive oxygen species. In addition, the prodrug displayed promising antiproliferative effects against two p53-mutated cell lines possessing SKOV-3 and DU145, with $\mathrm{IC}_{50}$ values of as low as $1 \mu \mathrm{mol} / \mathrm{L}$. It was verified by confocal imaging and gene expression analysis that the cytotoxicity of this metallodrug came from an apoptotic pathway.

\section{Dual Inhibitors Based on Intercalators}

In 2018, Chen et al reported a new series of acridine hydroxamic acid derivatives targeting both Topo and HDAC. ${ }^{26}$ Among these compounds, compound $\mathbf{8 c}$ (- Fig. 10) showed the best enzyme inhibitory activity. In addition to having micromolar level enzyme inhibitory activity, it also showed nanomolar $\mathrm{IC}_{50}$ values against U937 cells. What's more, 8c interacted with DNA and induced U937 apoptosis through both endogenous and exogenous pathways.

Ling et al reported a novel series of hybrid derivatives as dual inhibitors. ${ }^{27}$ The most potent compound YL-11c (-Fig. 11) showed good HDAC inhibitory antiproliferative effects in vitro. Meanwhile, YL-11c cleaved both PARP and caspase 3, triggering cancer cell apoptosis. Furthermore, YL11c enhanced expression of histone H2AX phosphorylation<smiles>O=C(O)CCn1cc(-c2ccc(Nc3c4ccccc4nc4ccccc34)cc2)nn1</smiles>

Fig. 10 Structure of acridine hydroxamic acid derivative 8c.

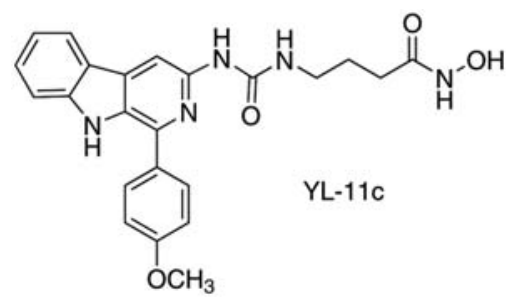

Fig. 11 Structure of hybrid derivative YL-11c. and p-p53 (Ser15), which were usually used as DNA damage markers.

\section{Conclusion}

Due to the importance of DNA and HDAC in cancer therapy, some dual inhibitors targeting DNA and HDACs have been developed and evaluated. In this review, we overviewed the newest studies and summarized their biology activity. Several molecules targeting DNA and HDACs showed excellent activity against cancer cell lines. With their excellent activity, they may become hopeful candidates and valuable tools to illuminate their mechanism for cancer therapy.

\section{Funding}

This work was supported by National Natural Science Foundation of China (81874288 and 21672127), ChinaAustralia Centre for Health Sciences Research (CACHSR No. 2019GJ07), Shandong Provincial Natural Science Foundation (No. ZR2019LZL004), the Key Research and Development Project of Shandong Province (Grant No. 2017CXGC1401), the Fundamental Research Funds of Shandong University (Grant No. 2019GN045), and the Joint Research Funds for Shandong University and Karolinska Institute (SDU-KI-2019-06).

\section{Conflict of Interest}

The authors declare no conflicts of interest.

\section{References}

1 Holohan C, Van Schaeybroeck S, Longley DB, Johnston PG. Cancer drug resistance: an evolving paradigm. Nat Rev Cancer 2013;13 (10):714-726

2 He B, Lu C, Zheng G, et al. Combination therapeutics in complex diseases. J Cell Mol Med 2016;20(12):2231-2240

3 Bayat Mokhtari R, Homayouni TS, Baluch N, et al. Combination therapy in combating cancer. Oncotarget 2017;8(23):38022-38043

4 Zimmermann GR, Lehár J, Keith CT. Multi-target therapeutics: when the whole is greater than the sum of the parts. Drug Discov Today 2007;12(1-2):34-42

5 Rosini M. Polypharmacology: the rise of multitarget drugs over combination therapies. Future Med Chem 2014;6(05):485-487

6 Bhaduri S, Ranjan N, Arya DP. An overview of recent advances in duplex DNA recognition by small molecules. Beilstein J Org Chem 2018;14:1051-1086

7 Venugopal B, Evans TR. Developing histone deacetylase inhibitors as anti-cancer therapeutics. Curr Med Chem 2011;18(11):1658-1671

8 Kim MS, Blake M, Baek JH, Kohlhagen G, Pommier Y, Carrier F. Inhibition of histone deacetylase increases cytotoxicity to anticancer drugs targeting DNA. Cancer Res 2003;63(21):7291-7300

9 Burchenal JH, Kalaher K, Dew K, et al. Studies of cross-resistance, synergistic combinations and blocking of activity of platinum derivatives. Biochimie 1978;60(09):961-965

10 Boddy AV, Yule SM. Metabolism and pharmacokinetics of oxazaphosphorines. Clin Pharmacokinet 2000;38(04):291-304

11 Schabel FM Jr. Nitrosoureas: a review of experimental antitumor activity. Cancer Treat Rep 1976;60(06):665-698

12 Kimball DB, Haley MM. Triazenes: a versatile tool in organic synthesis. Angew Chem Int Ed Engl 2002;41(18):3338-3351

13 Fong LY, Bevill RF, Thurmon JC, Magee PN. DNA adduct dosimetry and DNA repair in rats and pigs given repeated doses of procarbazine under conditions of carcinogenicity and human cancer 
chemotherapy respectively. Carcinogenesis 1992;13(11):21532159

14 Martínez R, Chacón-García L. The search of DNA-intercalators as antitumoral drugs: what it worked and what did not work. Curr Med Chem 2005;12(02):127-151

15 Lerman LS. Structural considerations in the interaction of DNA and acridines. J Mol Biol 1961;3:18-30

16 Mišković K, Bujak M, Baus Lončar M, Glavaš-Obrovac L. Antineoplastic DNA-binding compounds: intercalating and minor groove binding drugs. Arh Hig Rada Toksikol 2013;64(04):593-602

17 Pommier Y. Drugging topoisomerases: lessons and challenges. ACS Chem Biol 2013;8(01):82-95

18 Zhang B, Li X, Li B, Gao C, Jiang Y. Acridine and its derivatives: a patent review (2009 - 2013). Expert Opin Ther Pat 2014;24(06): 647-664

19 Khalaf AI, Al-Kadhimi AAH, Ali JH. DNA minor groove bindersinspired by nature. Acta Chim Slov 2016;63(04):689-704

20 Palchaudhuri R, Hergenrother PJ. DNA as a target for anticancer compounds: methods to determine the mode of binding and the mechanism of action. Curr Opin Biotechnol 2007; 18(06):497-503

21 Liu C, Ding $\mathrm{H}$, Li X, et al. A DNA/HDAC dual-targeting drug CY190602 with significantly enhanced anticancer potency. EMBO Mol Med 2015;7(04):438-449
22 Xie R, Li Y, Tang P, Yuan Q. Rational design, synthesis and preliminary antitumor activity evaluation of a chlorambucil derivative with potent DNA/HDAC dual-targeting inhibitory activity. Bioorg Med Chem Lett 2017;27(18):4415-4420

23 Xie R, Tang P, Yuan Q. Rational design and characterization of a DNA/HDAC dual-targeting inhibitor containing nitrogen mustard and 2-aminobenzamide moieties. MedChemComm 2017;9(02): 344-352

24 Griffith D, Morgan MP, Marmion CJ. A novel anti-cancer bifunctional platinum drug candidate with dual DNA binding and histone deacetylase inhibitory activity. Chem Commun (Camb) 2009;(44):6735-6737

25 McGivern TJP, Slator C, Kellett A, Marmion CJ. Innovative DNAtargeted metallo-prodrug strategy combining histone deacetylase inhibition with oxidative stress. Mol Pharm 2018;15(11): 5058-5071

26 Chen J, Li D, Li W, et al. Design, synthesis and anticancer evaluation of acridine hydroxamic acid derivatives as dual Topo and HDAC inhibitors. Bioorg Med Chem 2018;26(14):3958-3966

27 Ling Y, Xu C, Luo L, et al. Novel $\beta$-carboline/hydroxamic acid hybrids targeting both histone deacetylase and DNA display high anticancer activity via regulation of the $\mathrm{p} 53$ signaling pathway. J Med Chem 2015;58(23):9214-9227 